\title{
Household Consumption and Unconventional Monetary Policy: Insights from a Bayesian SVAR Model
}

\author{
Ebele AMALI \\ Department of Economics, Nile University of Nigeria, Abuja, Nigeria \\ E-mail: ebelea2001@nileuniversity.edu.ng
}

Tersoo Shimonkabir SHITILE (Corresponding author)

Central Bank of Nigeria / Department of Economics, Nile University of Nigeria, Abuja, Nigeria

E-mail: shimonkabir@gmail.com

Received: June 2, 2020

Accepted: July 24, 2020

Published: July 27, 2020

doi: $10.5296 /$ jsss.v7i2.17436

URL: https://doi.org/10.5296/jsss.v7i2.17436

\begin{abstract}
This study uses a Bayesian SVAR to demonstrate that movements in household consumption can be explained by expansionary credit easing policy. The latter reflects ongoing heterodox monetary policy regimes in many countries, especially emerging markets and developing economies (EMDEs). Using Nigeria's data over the period from Q1 1995 to Q4 2018, the empirical analysis reveals that the role of credit easing in the household consumption is not important in Nigeria, as a large part of the variation in household consumption can be explained by shocks to other economic activities. The findings also indicate a rough estimate that the impact threshold of credit easing on household consumption is no more than 2 percent, thus requiring accelerators and accelerator policy to overcome the threshold. Our results suggest the need for a broad-based policy response to fully maximize the positive effect of credit supply shock on private spending and aggregate demand in general.
\end{abstract}

Keywords: Unconventional Monetary Policy, Credit easing, Consumption, Bayesian VAR

\section{Background}

Monetary policy is a viable tool used to stabilize the business cycle, as fiscal policy measures result in permanent deficits (D'Acunto, Hoang, \& Weber, 2019). Thus, in the face of 
constrained effectiveness of conventional monetary policy tools, macroeconomists have recently encouraged the use of unconventional monetary policy (UMP) measures to generate the incentives to grow consumption by changing intertemporal prices. In a neoclassical model, changes in central bank credit easing intervention impact decisions of households to purchase durable goods through inflation expectations, and income (wealth effects). UMP is transmitted by affecting the consumption-saving decision of households. All things being equal, it is expected that households' income expectations will change with the implementation of expansionary credit policy. As for wealth effects, the response of household behavior to UMP measure will depend on the Ricardian equivalence condition. If Ricardian households exist, a credit easing intervention increase might result in a negative wealth effect. Inflation expectations are assumed to influence consumption decisions through a redistribution channel. Therefore, direct lending by the central bank (or credit easing interventions) can mitigate disruption in the intermediation of funds when frictions in the credit market are significant (Quint \& Rabanal, 2017). Within this context, the transmission channel of UMP is expected to impact the credit costs of borrowers directly and, therefore, the domestic demand. Therefore, a central research problem is whether a central bank-financed credit supply has led to higher aggregate domestic consumption spending.

The stabilising role of inflation expectations is accentuated in theoretical literature (Werning, 2012), as households with higher inflation expectations tend to purchase more durable goods. Jalil and Rua (2015) thus suggested that monetary and fiscal policy coordination i.e. something like monetary finance stimulus can boost higher inflation expectations and drive economic recovery from depression. The findings by Hausman and Wieland (2014) on the macroeconomic management intervention in Japan supports the view that policy-induced higher inflation expectation can raise consumption and output growth in an economy. Bachmann, Berg, and Sims (2015), however, did not find any relationship between inflation expectations and consumption propensities, thereby raising the question about the effectiveness of UMP. Besides, Del Negro, Giannoni and Patterson (2015) and McKay, Nakamura, and Steinsson (2015) contested the influence of UMP measure. Our paper contributes to this debate by quantifying and documenting the effect of UMP (credit easing interventions) on one particular aspect of welfare benefits, household consumption in Nigeria.

Few studies attempt to address the impact of the unconventional monetary policy on consumption. D'Acunto, Hoang and Weber (2019) argued that unconventional monetary policy stimulates consumption by managing inflation expectations based on the Euler equation. Quint and Rabanal (2017) show that while UMP is important in reacting to adverse financial shocks, it is not effective in tackling normal business cycle supply and demand shocks. They suggest that the policy measure supports lifetime consumption by 1.45 percent in the US. Empirical findings of Lukas (2017) indicate that non-standard monetary policy is welfare-improving via allowing the central bank to reclaim control over the domestic prices. De Fiore and Tristani (2019) also argued that the real economy could be insulated from deterioration in financial conditions using unconventional measures that targeted credit policy to efficiently empower households to change their intertemporal consumption patterns efficiently. Consequently, we add to the set of analyses considering the drivers of consumer 
spending, with a focus on the non-monetary policy measure in Nigeria.

The empirical analysis, therefore, takes a cue from Lenza, Phil, Reichlin and Ravn (2010) to estimate the transmission of unconventional monetary policy to the real economy. In this paper, we utilise the Bayesian structural vector autoregression (BVAR) including household consumption, central bank credit easing intervention, real gross domestic product, real market lending rate and public economic \& social spending quarterly variables during the period (Q1 1995 - Q4 2018) to perform a quantitative exercise on the CBN's UMP and household consumption spending interactions. To our knowledge, there is a dearth of empirical evidence on the impact of non-standard monetary policy measures on household consumption in Nigeria.

The rest of the paper is organized as follows. Section 2 presents stylised facts on household consumption and non-standard monetary policy in Nigeria, while section 3 looks at the model specification and estimation technique. Resulting econometric estimates are displayed and discussed in Section 4. Section 5 summarizes our main findings and draws some concluding remarks.

\section{Household Consumption Trend and Non-Standard Monetary Policy in Nigeria}

Household spending patterns tend to mirror the welfare of households and indicates the direction of the expenditure profile of the country (Anumudu, Asogwa, \& Eze, 2015). Available evidence suggests that the patterns of spending arising out of households' available income in Nigeria have evolved over the past two decades indicating household spending patterns skewed towards subsistence consumption. In 2016, the implied proportion of available disposable households' income spent on food and non-alcoholic beverages in Nigeria was estimated at 58.7 percent (Philips Consulting, 2016) and 56.4 percent (the United States' Department of Agriculture-ERS Food Expenditure Series) from 64.4 percent in 2003 (National Bureau of Statistics' Nigeria Living Standard Survey 2003-2004). The household final consumption spending (\% of GDP) in Nigeria numbers from the World Economic Indicators shows an upward trend with swings reflecting the economic developments. It moved from 9.8 percent in 1981 to 40.7 percent in 2000 with the restoration of democratic government. It stood at 76.6 percent in 2018 from an average of 64.7 percent in 2008/9 during the global financial crisis. This is in comparison to 62.6 and 58.3 percent average in sub-Sahara Africa (SSA) and the world, respectively, as depicted in Chart 1. 


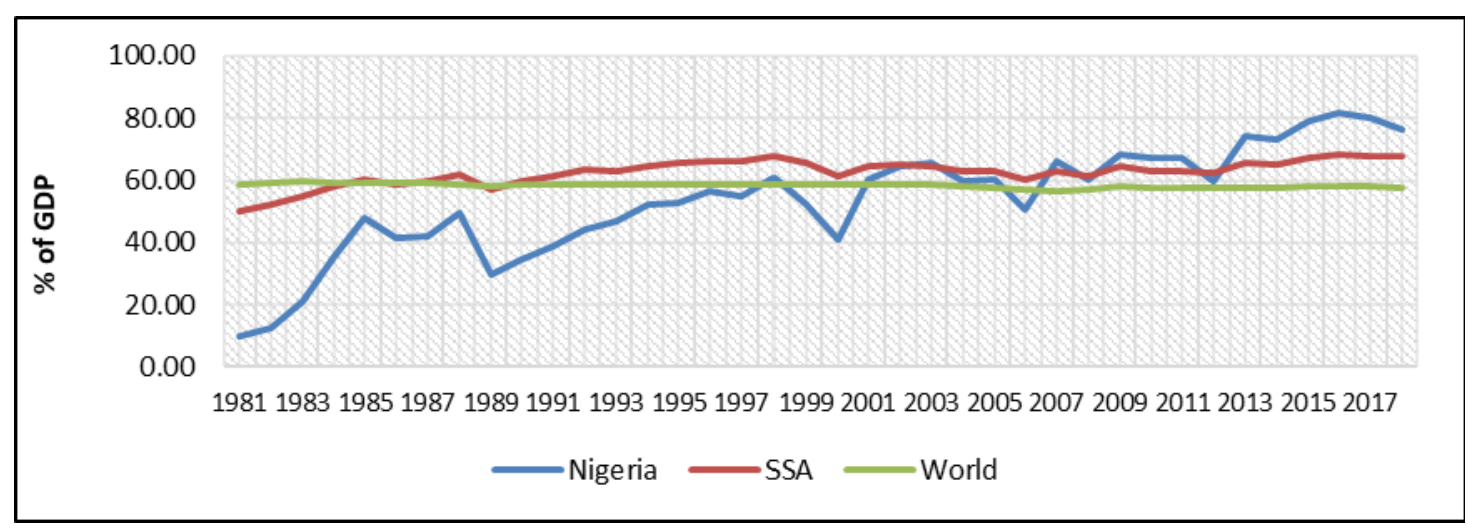

Source: Author's

Chart 1. Household \& Non-Profit Institutions Serving Households (NPISH) Final Consumption (constant 2010 US\$), percent of GDP

High expenditure on food and non-alcoholic beverages point toward its relative importance among the basic needs of the household; and with the marginal propensity to consume (MPC) at between 0.64 to 0.84 in Nigeria (Onanuga, Oshinloye, \& Onanuga, 2017; Kelikume, Alabi, $\&$ Anetor, 2017), it also affirms that consumption constitutes the main part of the aggregate spending and is a key driver of output growth in Nigeria. Consumption determines the size of the multiplier and the dynamic effects of economic shock.

In Nigeria, the objectives of monetary policy are derived from the Central Bank of Nigeria (CBN) Act 2007, which includes the core mandate of achieving price stability, sustainable output growth, low unemployment, and positive balance of payment position. To achieve these objectives, the Bank employs heterodox measures, a combination of interest rate to achieve low and stable inflation and apply the provision of special credits intervention directed at sectors such as agriculture, and manufacturing through the SMEs that will help in generating more employment. Over the years, the Bank has made significant inroads in development financing, which is seen as a non-standard monetary policy. Specifically, Section 31 of the CBN Act No. 7 of 2007 (as amended) empowers the Bank to carry out the developmental function of promoting the development of money and capital markets as well as stimulating economic development. The developmental function of the CBN conducted through the credit easing intervention policy is intended to mitigate financial market failure through appropriate measures that would help to grow the supply-side while managing the demand-side to ensure an optimal outcome.

Development financing in CBN began in 1964 when the Bank commenced the financing of the then commodity boards as directed by the Federal Government of Nigeria. By 2009-2010, there was a high roll out of development financing interventions by the Bank. This was justified by the need to stimulate the economy following the 2007-2008 global financial crisis. Another notable epoch was 2015-2019 when the Bank introduced several interventions to support the real sector and pulled the economy out of recession. It is instructive that these interventions are not peculiar to the CBN. It is the practice of many central banks, especially in developing economies to incorporate developmental roles in the mandate. 
The CBN's interventions during the global financial crisis (GFC) have had two major goals: strengthening the financial system through quantitative easing policy and direct support to enterprises with high potentials for job creation, forex conservation/import substitution, financial inclusion and other economic value. The interventions between 2009 to 2010 include Commercial Agriculture Credit Scheme (CACS), SME Restructuring \& Refinancing Facility (SMERRF), Micro, Small, Medium Enterprises Development Fund (MSMEDF), and Power and Aviation Intervention Fund (PAIF). Policies and programmes operationalized by CBN between 2013 to 2019 (post-GFC and during the 2016 economic recession) were Real Sector Support Facility (RSSF), Textile Sector Intervention Fund (TSIF), NEMSF, Anchor Borrowers' Programme (ABP), National Food Security Programme (NFSP), Youth Entrepreneurship Development Programme (YEDP), CBN-BOI Industrial Facility (CBIF), Nigeria Bulk Electricity Trading Payment Assurance Facility (NBET-PAF), Agric-Businesses/Small and Medium Enterprise Investment Scheme (AGSMEIS), Presidential Fertilizer Initiative (PFI), Accelerated Agricultural Development Scheme (AADS), Paddy Aggregation Scheme (PAS), Shared Agent Network Expansion Facility (SANEF), Export Development Facility (EDF), Real Sector Support Facility through Differentiated Cash Reserves Requirements (RSSF-DCRR), and Creative Industry Financing Initiative (CIFI).

In 2009, there was a shift in the focus of the Bank's intervention to the use of unconventional policy, credit easing, to address the financial system stability in the aftermath of the GFC. Therefore, the focus of interventions became: strengthening of the financial system and stimulating growth through the development of identified weak private sector. The use of home-grown heterodox policies of the CBN reflects the imperative to ensure that lending rates are stabilising conducive for the growth trajectory of the economy. The interventions now provide "direct support" to industries that have high job-creating capacity and other vital economic infrastructure such as power projects. For instance, the SME Restructuring and Refinancing Facility (SMERFF) and Power and Airline Intervention Facility (PAIF) were introduced to restructure/refinance deposit money banks (DMBs') exposures to the manufacturing sector and SMEs, boost electricity production, especially within industrial clusters, ensure the smooth flow of credit to the real sector of the economy, promote private sector/foreign investment as well as energize reforms in the power and other economic infrastructure sectors, and bring about growth in employment generation. In the same vein, the Anchor Borrowers' Programme (ABP) also provides resources for small-holder farmers who are the bedrock of Nigeria's agricultural sector.

The available literature on these heterodox monetary policies in Nigeria has established that the CBN's financial stimulus contributes significantly to the macroeconomy by improving the productive sectors, facilitating job creations and output growth (Onuigbo, Chinedu, and Biam, 2019; Olomola, 2018; Dori, 2016). However, there is a dearth of study on how the UMP fares in stimulating household consumption expenditure in the bid to ward off the negative impact of adverse economic and financial shocks. Thus, the study aims to quantify the effect of the non-standard measures of the CBN, particularly, credit easing policy on household consumption spending. The presence of such a consumption channel can support the understanding of the outcome of unconventional monetary policy. 


\section{Empirical Methodology}

\subsection{Model Specification}

The empirical model is defined as the following structural VAR (in a reduced form),

$$
y_{5}=\alpha+A_{1} y_{v-1}+A_{2} y_{v-2}+\cdots+A_{3} y_{v-z}+a_{v}
$$

where $y_{t}$ is a $\mathrm{n} \times 1$ vector of variables: household consumption (HC), central bank credit easing (CCE), public social and economic spending (PSES), real GDP (rGDP) and the real market lending rate (rLR) included in the system; where $\alpha$ is a $n \times 1$ vector of constants; where $A_{1}, A_{2}, A_{p}$ refers to $\mathrm{n} \times \mathrm{n}$ matrices of the autoregressive parameters, and $\varepsilon_{t}$ is a $\mathrm{n} \times 1$ vector of white noise error terms with a covariance matrix $E\left[g_{\tau} g_{t}^{l}\right]=\Psi$.

We assume a homogeneous wage response to unconventional monetary policy shocks across all households. Nakajima (2015) suggests that monetary policy stimulus can reduce households' risk of unemployment. As a result, households might experience higher income increases from unconventional monetary policy shock through the wage channel. Following this perspective, the econometric analysis framework reflects the objective to answer the important question of to what extent household consumption has been driven by unconventional monetary policy in the form of central bank credit easing interventions, and how sensitive consumption of households is to changes in the state of macroeconomic variables?

Also based on the understanding that the interaction between unconventional monetary policy and real variables especially aggregate demand could be conditional to structural changes or economic environment (Bank for International Settlements, 2019), the traditional approach to identifying the dynamic effect of shocks relies on structural Vector-Auto regression (VARs) which is a linear model. Therefore, for policy analysis, it is appealing to use prior information in VARs to overcome the problem of overfitting. That is to say, VAR models allow the data to speak more freely by imposing fewer restrictions on the data, unlike theory-based Dynamic Stochastic General Equilibrium models.

\subsection{Estimation Technique}

The Bayesian -SVAR model:

Following Hanck and Prüser (2020), the SVAR model with 5 variables can be written as,

$$
y_{t}^{k}=\sum_{i=1}^{p} y_{t-t}^{t} A_{t}+x_{t}^{i} C+a_{t}^{t}
$$

The equation (1) can be further revised by stacking the data as a multivariate regression model as

$$
y_{t}^{t}=z_{t}^{l n}+a_{t}^{t}
$$

where $y_{t}$ is a $\mathbf{5} \times 1$ vector comprising the variables at time $t, A_{i}$ a $\mathbf{5} \times \mathbf{5}$ matrix of parameters, $x_{t}$ is a vector of $d$ deterministic variables at a time $t, \mathrm{C}$ a $d \times 5$ parameter

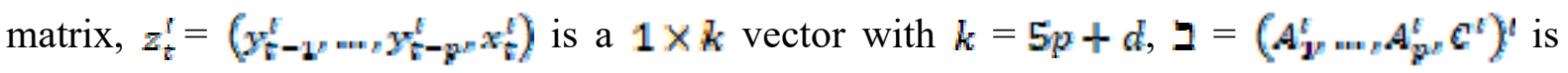


a $k \times 5$ matrix and $s_{\tau} \sim N(0, \Psi)$ are normally distributed errors.

To help reduce the problem of degrees of freedom arising from the parameterisation that characterises conventional VAR models, which might lead to uncertainty and imprecise inference, we used BVAR framework (Note 1) to solve the dimensionality problem by setting prior values to shrink the estimated parameters of the model. Thus, in this context, the gain of BVAR model is to strengthen inferences about the true value of the parameters using their prior and likelihood functions as well as posterior distribution. And the probability distributions for the autoregressive parameters in the VAR are determine based on the posterior distribution. For this study, we adopt the Litterman/Minnesota prior which assumed that $\Sigma_{t}$ is known. Further, we also adopt the univariate AR where $\widehat{\Sigma}_{\varepsilon}$ has a diagonal matrix restriction and $\hat{\Theta}_{i t}^{2}$ is the estimator of the error variance of the $i$-th variable from a univariate AR regression (Alenoghena, 2017).

The posterior probabilistic distribution is expressed as,

$$
\pi(\delta \mid y)=f(y \mid \delta) \pi(\delta) / f(y)
$$

where $\delta$ a vector of autoregressive parameters in the VAR, the posterior distribution conditional to the sample information contained in the vector is captured by $\pi(\delta \mid y), f(y \mid \delta)$ denotes the likelihood function, $\pi(\delta)$ is the prior distribution about the parameters and $f(y)$ represents the density function of the data in the sample which is used as a means to standardise. Hence, equation (2) is restated as,

$$
\pi(\& \mid y) \times f(y \mid \delta) \pi(8)
$$

The distribution of $\delta$ is assumed to be $W\left(\delta_{\alpha} \Omega_{Q}\right)$ while for each variable in the model, the autoregressive parameter is set equal to 1 , and 0 for the rest (Cuetas,2017). The variance of the parameters is then specified as,

$$
\begin{gathered}
\sigma_{\delta_{i t}^{2}}^{2}=\left(\lambda_{1} / \lambda_{i}\right)^{2} \\
\sigma_{\delta_{i t}^{2}}^{2}=\left(\sigma_{i}^{2} / \sigma_{i}^{2}\right)\left(\lambda_{1} \lambda_{2 / t_{i}}\right)
\end{gathered}
$$

where, $\sigma_{i}^{2}$ and $\sigma_{i}^{2}$ refer to the ordinary least squares residual variance for the autoregressive models for variables $i$ and $i, l$ is the lag for the coefficient, while $\lambda_{1}, \lambda_{2}$ and $\lambda_{3}$ are scalars respectively for overall tightness (the own lag variance), relative cross-variable weight, and the lag decay (scaling constant controlling the speed of convergence to 0 for the coefficients of lags greater than 1). Following Cuestas (2017), $\lambda_{1}$, $\lambda_{2}$ and $\lambda_{3}$ is set equal to $0.2,0.5$ and 1.0 , respectively.

Subsequently, applied structural data generating process takes the form;

$$
\delta_{Q} y_{t}=\delta(L) y_{t}+e_{t}
$$


where $\delta_{0}$ is the matrix of contemporaneous restrictions, $\delta$ is a matrix of coefficients for the lagged variables, and $L$ is the lag operator in polynomial form.

\subsection{Data}

All data are quarterly and spanning the period Q1 1995 - Q4 2018. The data were obtained from CBN statistical database and statistical bulletin. Table 1 shows the descriptive statistics for growth in real GDP (rGDP), central bank credit easing (CCE), household consumption (HC), real lending rate (rLR), public social and economic spending (PSES), respectively.

Table 1. Descriptive statistics of variables

\begin{tabular}{llllll}
\hline & rGDP & CCE & HC & rLR & PSES \\
\hline Mean & 10902.90 & 1602.790 & 6601.492 & 9.271875 & 968.1566 \\
Median & 10353.61 & 50.15695 & 6067.215 & 11.70000 & 756.7769 \\
Maximum & 19041.44 & 5918.143 & 12404.20 & 28.63000 & 2541.848 \\
Minimum & 4999.305 & 5.202490 & 2358.759 & -58.60000 & 54.67548 \\
Std. Dev. & 4557.904 & 2298.041 & 3053.946 & 13.41756 & 678.0964 \\
Skewness & 0.205708 & 0.880348 & 0.205669 & -3.038239 & 0.353426 \\
Kurtosis & 1.601329 & 1.849087 & 1.650012 & 13.94958 & 1.877323 \\
Jarque-Bera & 8.502181 & 17.69860 & 7.966665 & 627.2673 & 7.040182 \\
Probability & 0.014249 & 0.000143 & 0.018623 & 0.000000 & 0.029597 \\
Observations & 96 & 96 & 96 & 96 & 96 \\
\hline
\end{tabular}

Source: Authors' computation

The empirical means for all the variables are positive. It can be shown that real GDP, central bank credit easing, household consumption, and public social and economic spending were positively skewed, while the real lending rate is negatively skewed; the implication of these is that the positively skewed variables have more rises than falls and vice- versa for the negatively skewed variables. It is obvious from the table that all the variables have kurtoses value far greater or lesser than 3 , which violate the property of normally distributed variables. The probability values of the Jarque-Bera normality test were statistically significant for the variables, and this signifies that the variables do not follow a normal distribution. However, this issue of non-normality may be taken with a grain of salt due to the asymptotic theory or the law of large numbers. The variables are transformed into percentage change (variables in lower case) to ensure stationarity for estimation, and the unit root result is discussed below.

\section{Empirical Results}

\subsection{Unit Root Test}

Augmented Dickey-Fuller (ADF) and Philips Perron (PP) unit root tests were employed to 
identify integration degree of the variables. The results displays in Table 2 showed that all the variables were stationary at a $1 \%$ significance level. We, therefore, included the first difference of the variables in the model.

Table 2: Unit root test result

\begin{tabular}{lcc}
\hline Variables & ADF test-stat & P-P test-stat \\
\hline$r G D P_{\tau}$ & $-12.3187 * * *$ & $-12.1732 * * *$ \\
$C C E_{t}$ & $-10.5500 * * *$ & $-10.5583 * * *$ \\
$E C_{t}$ & $-11.7489 * * *$ & $-12.1490 * * *$ \\
$r L R_{v}$ & $-7.7685 * * *$ & $-7.7587 * * *$ \\
FSES & $-4.4860 * * *$ & $-5.7515 * * *$ \\
\hline
\end{tabular}

Source: Authors' computation

$(* * *)$ denotes significance at $1 \%$ level

Moreover, the order of integration of the variables is not a problem in this case as inference is not based on standard $t$ statistics and frequentist asymptotic approach.

\subsection{Lag Selection}

Table 3. Lag selection by an information criterion

\begin{tabular}{lllllll}
\hline Lag & LogL & LR & FPE & AIC & SC & HQ \\
\hline 0 & -3176.99 & NA & $1.76 \mathrm{e}+25$ & 72.32 & 72.46 & 72.37 \\
1 & -2767.57 & 763.02 & $2.83 \mathrm{e}+21$ & 63.58 & 64.43 & 63.92 \\
2 & -2736.04 & 55.19 & $2.45 \mathrm{e}+21$ & 63.43 & 64.98 & 64.06 \\
3 & -2688.53 & 77.74 & $1.49 \mathrm{e}+21$ & 62.92 & 65.17 & 63.83 \\
4 & -2621.50 & 102.07 & $5.88 \mathrm{e}+20$ & 61.97 & 64.92 & 63.16 \\
5 & -2542.12 & 111.84 & $1.79 \mathrm{e}+20$ & 60.73 & $64.39^{*}$ & 62.20 \\
6 & -2503.33 & 50.25 & $1.40 \mathrm{e}+20$ & 60.42 & 64.78 & 62.17 \\
7 & -2469.41 & 46.89 & $1.25 \mathrm{e}+20$ & 60.21 & 65.28 & 62.26 \\
8 & -2425.51 & $40.09^{*}$ & $9.35 \mathrm{e}+19^{*}$ & $59.78^{*}$ & 65.56 & $62.11^{*}$ \\
\hline
\end{tabular}

* indicates lag order selected by the criterion

LR: sequential modified LR test statistic (each test at 5\% level)

FPE: Final prediction error

AIC: Akaike information criterion 
SC: Schwarz information criterion

HQ: Hannan-Quinn information criterion

The lag selection result as presented in Table 3 shows that LR, FPE, AIC, and HQ criteria select optimal lag eight, while SC selects optimal lag five for the VAR (p) model. VAR model estimation is highly sensitive to the nature of the data generating process, which depends on the choice of lag length. However, we stick to the result of a VAR model that produced the best result.

\subsection{Bayesian SVAR Estimates}

Table 4 shows output relating to the dependent variables in the VAR models. From the results, household consumption strongly influenced itself and the one-period lag of aggregate income (GExp(-1)) predicts household consumption going by t-statistic values of 3.17 and 3.34, respectively. Therefore, the past realization of household consumption is associated with a 24 percent increase in household consumption ceteris paribus even as $\operatorname{rGDP}(-1)$ accounts for a 23 percent increase in household consumption. In contrast, the marginal effects of non-standard monetary policy in the form of central bank credit easing, public social \& economic spending, and real market lending rate do not have statistically significant on household consumption with the t-statistic values of $0.44,1.66$ and 0.53 , respectively. At the same time, (increase) real market lending rate shows a negative impact on household consumption. This affirmed the position in the empirical literature that reductions in interest rate can improve cash-flow and liquidity constraint problems of the household (Di Maggio, Kermani and Ramcharan, 2014). The results also seem to suggest that the central bank credit easing implementation does not significantly benefit the economy by boosting aggregate income and stabilising real market lending rate.

Checking the robustness of the result, adjust the coefficient of determination of household consumption model, after taking into consideration the degree of freedom, indicates that 93 percent of the variation in the dependent variable (household consumption) is influenced by the explanatory variables in the model. Also, from the value of the F-statistic (129.09), the explanatory variables are jointly significant in explaining household consumption model.

Table 4. BVAR Estimates (Hyper-parameters: Mu: 0, L1: 0.1, L2: 0.99, L3: 1)

\begin{tabular}{llllll}
\hline Variables & Models & \multicolumn{5}{l}{} \\
\hline & HC & CCE & PSES & rGDP & rLR \\
\hline HC(-1) & 0.2390 & -0.0389 & -0.0038 & 0.1985 & -9.2501 \\
& $(3.1688)$ & $(-1.0066)$ & $(-0.6382)$ & $(2.7345)$ & $(-0.2709)$ \\
CCE(-1) & 0.0415 & 0.6987 & -0.00450 & 0.1332 & 0.0003 \\
& $(0.4385)$ & $(14.2285)$ & $(-0.6709)$ & $(1.4546)$ & $(0.8029)$ \\
PSES(-1) & 0.9069 & -0.0786 & 0.9239 & 1.1236 & 0.0033 \\
& $(1.6620)$ & $(-0.2794)$ & $(21.3909)$ & $(2.1282)$ & $(1.3390)$ \\
\hline
\end{tabular}




\begin{tabular}{llllll}
\hline rGDP(-1) & 0.2296 & 0.0678 & 0.0080 & 0.4523 & -0.0004 \\
& $(3.3399)$ & $(1.9135)$ & $(1.4728)$ & $(6.7745)$ & $(-1.1824)$ \\
rLR(-1) & -5.9046 & 0.9458 & -0.8048 & -6.0298 & 0.5844 \\
& $(-0.5259)$ & $(0.1633)$ & $(-0.9112)$ & $(-0.5551)$ & $(11.3543)$ \\
C & 706.6409 & -502.8736 & -9.1743 & 1964.559 & 6.1585 \\
& $(2.0615)$ & $(-2.8435)$ & $(-0.3402)$ & $(5.9139)$ & $(3.9435)$ \\
Adj.R & 0.93 & 0.97 & 0.99 & 0.97 & 0.84 \\
F-test & 129.09 & 267.45 & 672.92 & 288.98 & 51.38 \\
\hline
\end{tabular}

*t-statistics in ( )

Note: If the t-statistics is greater than 2, the variable in question has a significant impact on the dependent variable

Source: Author's computation

Also, causality check using regressors' t-statistics, looking at household consumption model, we can infer that only rGDP(-1) are strongly significant, and have a short-run causal effect on household consumption. We can also observe that given t-statistics value, central bank credit easing, the public social \& economic spending, and the real market lending rate have no short-run causal effect on the variable on interest, household consumption.

In line with Lütkepohl (1991) interpretation, the inverse roots of the characteristic AR polynomial in Chart 2 shows that the estimated B-SVAR is stable which confirms that further probes from B-SVAR results such as impulse response and variance decomposition standard errors are valid.

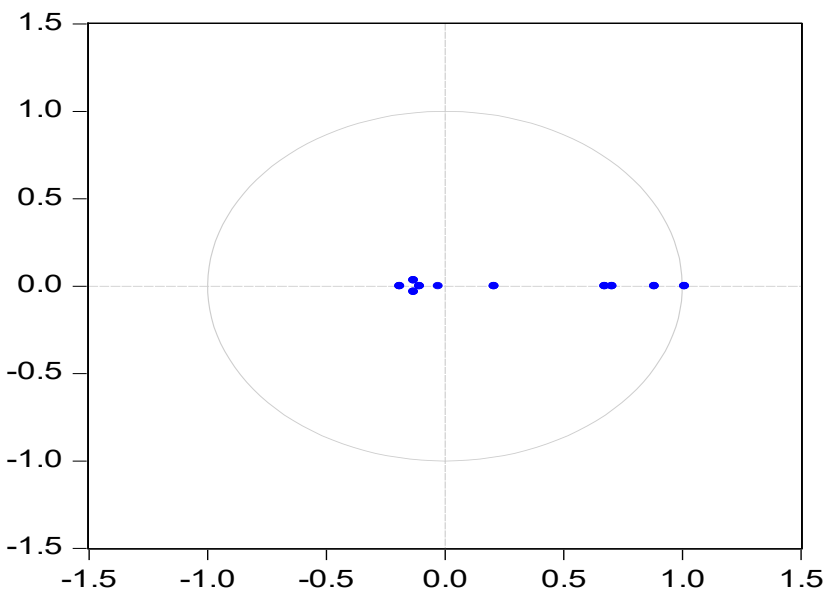

Chart 1. AR Roots Graph

\subsection{Impulse Response Function and Variance Decomposition}

From the Impulse Response Function graph, Chart 3 indicates that one standard deviation (sd) innovation to central bank credit easing has a mildly positive impact on households' 
consumption in quarters 1 and 2 but persist in its steady-state value in the remaining period (quarter 3 to 10). This suggests that shock to central bank credit easing has limited impacts on households' consumption in the short-run and long-run in Nigeria during the period under review. At a rough estimate, credit easing has no more than a 2 percent impact threshold on household consumption. The result also shows that household consumption responds positively to one standard deviation innovation shock in its self, to public social \& economic spending and real GDP. Expectedly, household consumption responds negatively to one standard deviation innovation shock in the real market lending rate.

To quantify the contributions of central bank credit easing policy shocks to variations in household consumption, we employed the variance decomposition method. Table 5 displays the variance decomposition result for household consumption. The result shows that in the short-run (quarter 1 to 5), 83 percent forecast variance in household consumption is explained by the aggregate income (real GDP) while the other variables in the model including credit easing of the central bank do not have a strong influence on household consumption. Only less than 3 percent of the variations of household consumption is explained by central bank credit supply shock. The share of its own (household consumption) shock, government spending shock, and interest rate shock is about 27,7 , and 0.4 percent, respectively, for 10 quarters. This suggests that household consumption shows a strong influence on itself right from in the future, which confirms the B-SVAR estimates.

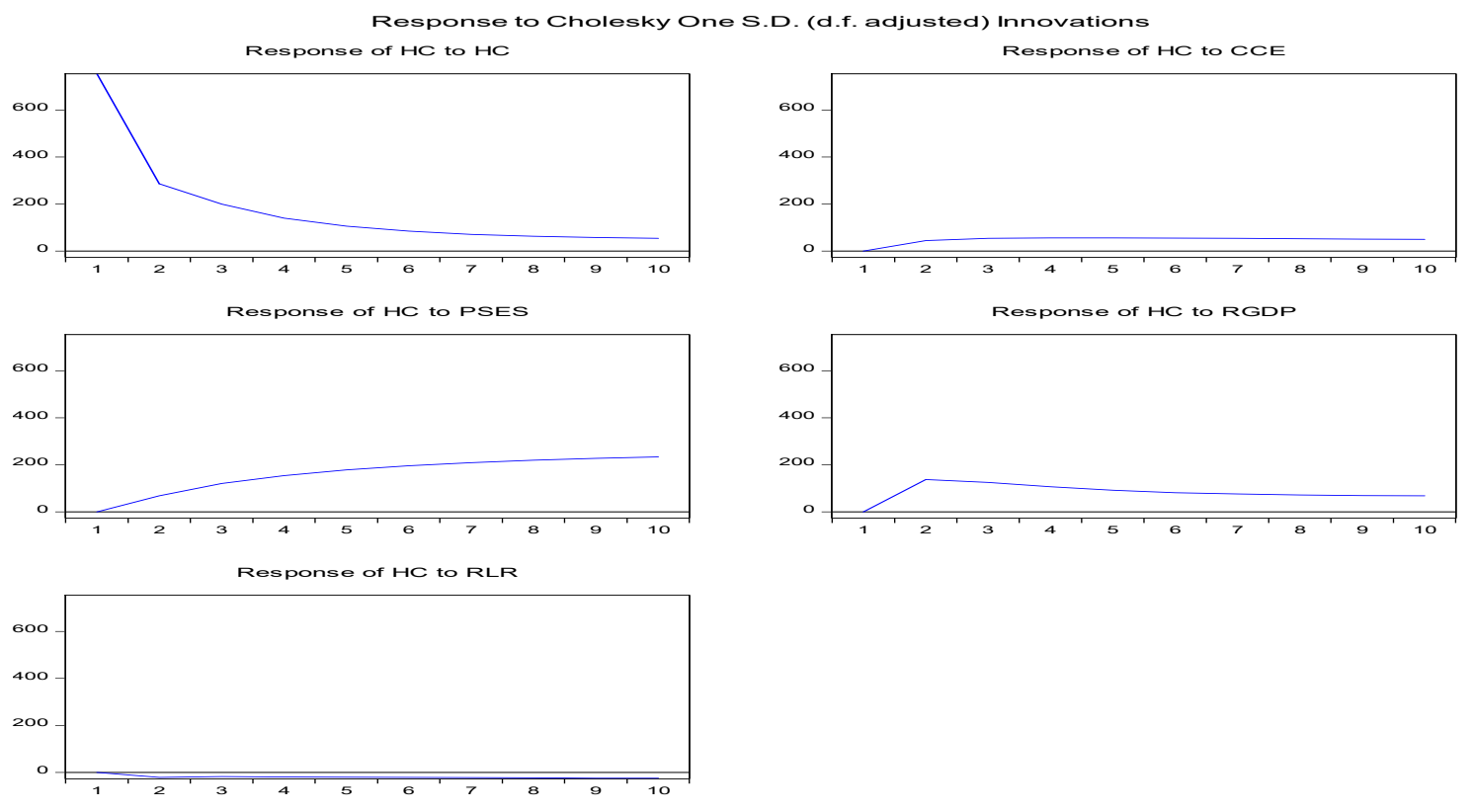

Chart 2. Response of Household Consumption to Innovations from Itself, Central Bank Credit Easing, Public Social \& Economic Spending, Real GDP and Real Lending Rate 
Table 5. Variance decomposition of household consumption

\begin{tabular}{lllllll}
\hline Period & S.E. & Shock $1 *$ & Shock 2 & Shock 3 & Shock 4 & Shock 5 \\
\hline 1 & 753.07 & 0.00 & 100.00 & 0.00 & 0.00 & 0.00 \\
2 & 821.73 & 0.69 & 96.16 & 0.29 & 0.07 & 2.78 \\
3 & 865.02 & 2.55 & 92.11 & 0.65 & 0.11 & 4.58 \\
4 & 897.95 & 5.32 & 87.91 & 0.99 & 0.14 & 5.64 \\
5 & 928.03 & 8.68 & 83.61 & 1.28 & 0.18 & 6.25 \\
6 & 957.54 & 12.34 & 79.31 & 1.53 & 0.22 & 6.60 \\
7 & 987.22 & 16.09 & 75.13 & 1.74 & 0.26 & 6.78 \\
8 & 1017.26 & 19.79 & 71.14 & 1.90 & 0.29 & 6.88 \\
9 & 1047.64 & 23.36 & 67.37 & 2.023 & 0.33 & 6.92 \\
10 & 1078.30 & 26.74 & 63.85 & 2.12 & 0.37 & 6.92 \\
\hline
\end{tabular}

*Shock 1, Shock 2, Shock 3, Shock 4 and Shock 5 indicate consumption shock, aggregate income shock, Central bank credit supply shock, interest rate shock and government spending shock, respectively.

\section{Conclusion}

Emerging markets and developing economies (EMDEs) have been implementing heterodox monetary policy, and the unconventional policy measures increased during and after the 2008/09 global financial crisis. Whether these measures have boosted aggregate demand remains the most important question. This study empirically investigates the link between central bank credit easing and household consumption in Nigeria using prior information to obtain more precise VAR estimates of impulse response functions. Specifically, the empirical analysis using Nigeria's data over the period from Q1 1995 to Q4 2018 reveals that unconventional monetary policy in the form of credit easing by the central bank is a positive but insignificant decisive factor to household consumption. Overall, the results of the impulse response functions and variance decomposition indicate that household consumption movement can be better explained by other fundamental or local factors of the economy than the expansionary credit easing policy.

The findings also indicate that credit easing has no more than a rough estimate of a 2 percent impact on household consumption, which may need accelerators and accelerator policy to overcome the threshold. This persistent placid response of household consumption to credit supply shocks suggests that expansionary credit policy interventions have not substantially contributed to the level of aggregate demand. While the results of this study affirm Amaral (2017)'s finding that the magnitude of welfare consequences of unconventional monetary policy is small, it further attests to the undercurrent of capacity limitations hindering output adjustment and prices flexibility - supply side, and the structural parameters shaping the dynamics of household consumption - demand side (Kandil, 2014) that could impact the 
growth of consumption in the face of unconventional monetary policy shocks.

Our results can inform the discussion on the consumption channel of unconventional monetary policy. It points towards deploying a credible monetary- fiscal policy coordination and acceleration strategy at addressing structural rigidities that obstruct the transmission mechanism of monetary injection via credit easing, distort the income-demand elasticity, and hinder output adjustment to maximising the positive effect of credit supply on private spending.

Future research using a structural moving-average representation of the economy and approximating the impulse response functions through Gaussian basis functions would allow considering the non-linear dynamic effect of structural shock (Jannsen, Potjagailo, \& Woltersa,2019; European Parliament, 2016) from non-standard monetary policy to household consumption.

\section{Reference}

Alenoghena, R. O. (2017). Financial Inclusion and per Capita Income in Africa: Bayesian Var Estimates. Acta Universitatis Danubius of Economica, Danubius University of Galati, 13(5), 201-221.

Amaral, P. S. (2017). Monetary Policy and Inequality. Economic Commentary, Federal Reserve Bank of Cleveland. https://doi.org/10.26509/frbc-ec-201701

Anumudu, C. N., Asogwa, I. S., \& Eze, O. (2015). 0386 Effects of Household Expenditure Patterns on Nigeria Poverty Odds. International Journal of Economics, Commerce and Management, 3(4).

Bachmann, R., Berg, T. O., \& Sims, E. (2015). Inflation expectations and readiness to spend: cross-sectional evidence. American Economic Journal: Economic Policy, 7(1), 1-35. https://doi.org/10.1257/pol.20130292

Bank for International Settlements, 2019, Unconventional monetary policy tools: a cross-country analysis. Committee on the Global Financial System (CGFS) Papers No 63. Available at https://www.bis.org/publ/cgfs63.pdf

Central Bank of Nigeria Act. (2007). Accessed at http://www.cenbank.org/ out/Eduseries/institutional. CBN Act, 2007.

Cuestas, J. C. (2017). House prices and capital inflows in Spain during the boom: Evidence from a cointegrated VAR and a structural Bayesian VAR. Journal of Housing Economics, 37(C), 22-28. https://doi.org/10.1016/j.jhe.2017.04.002

D'Acunto, F., Hoang, D. \&Weber, M. (2019). Managing Households' Expectations with Salient Economic Policies. CESifo Working Paper Series, 7793, CESifo Group Munich. https://doi.org/10.2139/ssrn.3435145

De Fiore, F., \& Tristani, O. (2019). (Un)conventional policy and the effective lower bound. BIS Working Papers 804, Bank for International Settlements. https://doi.org/10.1016/j.jedc.2019.05.003

Del Negro, M., Giannoni, M. P., \& Patterson, C. (2015). The forward guidance puzzle. FRB of New York Staff Report (574).

Di Maggio, M., Kermani, A., \& Ramcharan, R. (2014). Did low interest rates boost 
households' consumption? VOX CEPR Policy Portal.

Dori, N. A. S. (2016). The Impact of Central Bank of Nigeria's Development Finance on Economic Growth and Development of Nigeria. Afro Asian Journal of Social Sciences, VII.

European Parliament. (2016). Transmission channels of unconventional monetary policy in the euro area: where do we stand? Monetary Dialogue 28 November 2016.

Hanck, C., \&Prüser, J. (2020). House Prices and Interest Rates - Bayesian Evidence from Germany. erscheint in Applied Economics. https://doi.org/10.1080/00036846.2019.1705242

Hausman, J. K., \& Wieland, J. F. (2014). Abenomics: Preliminary Analysis and Outlook' Brookings Paper, 1-63. https://doi.org/10.1353/eca.2014.0001

Jalil, A., \&Rua, G. (2015). Inflation expectations and recovery from the depression in 1933: Evidence from the narrative record. Unpublished Manuscript, Federal Reserve Board. https://doi.org/10.2139/ssrn.2604164

Jannsen, N., Potjagailo, G., \& Woltersa, M. H. (2019). Monetary Policy during Financial Crises: Is the Transmission Mechanism Impaired? International Journal of Central Banking, 15(4).

Kandil, M. (2014). On the effects of monetary policy shocks in developing countries Author links open overlay panel. Borsa Istanbul Review, 4(2), 104-118. https://doi.org/10.1016/j.bir. 2014.04.001

Kelikume, I., Alabi, F., \& Anetor, F. O. (2017). Nigeria Consumption Function - An Empirical Test of the Permanent Income Hypothesis, Journal of Global Economics, Management and Business Research, 9(1), 17-24.

Lenza, M., Pill, H., Reichlin, L., \& Ravn, M. (2010). Monetary policy in exceptional times. Economic Policy, 25(62), 295-339. https://doi.org/10.1111/j.1468-0327.2010.00240.x

Lukas, A. (2017). Inside money, investment, and unconventional monetary policy. ECON Working Papers 247, Department of Economics - University of Zurich, revised Jul 2019.

Lütkepohl, H. (1991). New introduction to multiple time series analysis. Berlin: Springer Science \& Business Media. https://doi.org/10.1007/978-3-662-02691-5

McKay, A., Nakamura, E., \&Steinsson, J. (2015). The power of forward guidance revisited. Technical report, National Bureau of Economic Research.

Nakajima, M. (2015). The Redistributive Consequences of Monetary Policy. Federal Reserve Bank of Philadelphia, Business Review, 9-16.

National Bureau of Statistics. (2003). LSMS Integrated Surveys on Agriculture Nigeria General Household Survey Panel 2003/2004.

Olomola, A. (2018). Financial Stimulus and Performance of the Commercial Agricultural Credit Scheme (CACS) in Nigeria. 2018 Conference, July 28-August 2, 2018, Vancouver, British Columbia 277445, International Association of Agricultural Economists.

Onanuga, A., Oshinloye, M., \& Onanuga, O. (2017). Income and Household ConsumptionExpenditure in Nigeria. MPRA Paper No. 83332. Retrieved from https://mpra.ub.uni-muenchen.de/83334/MPRA Paper No. 83334

Onuigbo, I., Chinedu, U. J., Orefi, A., \& Biam, C. K. (2019). Poverty alleviation through cereal production in Nigeria: the role of agricultural credit guaranteed scheme fund. 2019 


\section{Macrothink}

Journal of Social Science Studies

ISSN 2329-9150

2020, Vol. 7, No. 2

Sixth International Conference, September 23-26, 2019, Abuja, Nigeria 295730, African Association of Agricultural Economists (AAAE).

Philips Consulting. (2016). The 2016 Online Shopping Survey Report.

Quint, D., \& Rabanal, P. (2017). Should unconventional monetary policies become conventional? Discussion Papers 28/2017, Deutsche Bundesbank. https://doi.org/10.5089/ 9781475591330.001

Werning, I. (2012). Managing a liquidity trap: monetary and fiscal policy. Unpublished Manuscript, MIT. https://doi.org/10.3386/w17344

\section{Copyright Disclaimer}

Copyright for this article is retained by the author(s), with first publication rights granted to the journal.

This is an open-access article distributed under the terms and conditions of the Creative Commons Attribution license (http://creativecommons.org/licenses/by/4.0/). 